\title{
Anterior chest hump in adolescent idiopathic scoliosis- questionnaire evaluation
}

\author{
K Watanabe*, N Hosogane, K Chiba, Y Toyama, M Matsumoto \\ From 8th International Conference on Conservative Management of Spinal Deformities and SOSORT 2011 \\ Annual Meeting \\ Barcelona, Spain. 19-21 May 2011
}

\section{Background}

Thoracic hump, shoulder imbalance, lumbar hump were known as trunk deformities associated with scoliosis bothering patients. In addition to these deformities, anterior chest hump $(\mathrm{ACH})$ occurring at the distal end of the anterior chest wall on the convex side, may be another noteworthy problem. We evaluated how much patients with adolescent idiopathic scoliosis (AIS) were bothered by $\mathrm{ACH}$ based on our original questionnaires conducted in patients undergoing surgery.

\section{Materials and methods}

Fifty-seven AIS patients (all females) who underwent surgical treatment were included in this study. A mean age at the time of surgery was $17.2 \pm 4$.6years. A mean preoperative Cobb angle of the main thoracic curve was $58 \pm 14^{\circ}$. The questionnaire consisted of five numerically-rated questions asking how much the patient was bothered by thoracic hump, lumbar hump, $\mathrm{ACH}$, waist asymmetry, and shoulder imbalance. The perception about the deformities was scored from 0 (None) to 10 (Worst). Correlation between the score of $\mathrm{ACH}$ and thoracic Cobb angle was also evaluated.

\section{Results}

The mean score of $\mathrm{ACH}$ was $3.8 \pm 3.4$ points, which was almost equal to that of lumbar hump (3.9 \pm 3.7 points). The mean scores were $5.8 \pm 3$.9points in waist asymmetry, $5.7 \pm 3.5$ points in thoracic hump, and $4.9 \pm 3.4$ points in shoulder imbalance. The score of $\mathrm{ACH}$ was significantly correlated with thoracic Cobb angle (correlation coefficient: $0.43, \mathrm{p}<0.001)$.

Keio University, Tokyo, Japan

\section{Conclusions}

The results indicated that $\mathrm{ACH}$ was bothering problem for AIS patients similarly to other trunk deformities. Since the perception of trunk deformity reported to be strongly associated with patient satisfaction for treatments [1], ACH should be noted as one of the trunk deformities bothering patients.

Published: 27 January 2012

\section{Reference}

1. Sanders JO, Carreon LY, Sucato DJ, Sturm PF, Diab, Spinal Deformity Study Group: Preoperative and perioperative factors effect on adolescent idiopathic scoliosis surgical outcomes. Spine 2010, 35(20):1867-71.

doi:10.1186/1748-7161-7-S1-011

Cite this article as: Watanabe et al: Anterior chest hump in adolescent idiopathic scoliosis- questionnaire evaluation. Scoliosis 2012 7(Suppl 1):011.

Submit your next manuscript to BioMed Central and take full advantage of:

- Convenient online submission

- Thorough peer review

- No space constraints or color figure charges

- Immediate publication on acceptance

- Inclusion in PubMed, CAS, Scopus and Google Scholar

- Research which is freely available for redistribution

\section{Biomed Central}

(c) 2012 Watanabe et al; licensee BioMed Central Ltd. This is an open access article distributed under the terms of the Creative Commons Attribution License (http://creativecommons.org/licenses/by/2.0), which permits unrestricted use, distribution, and reproduction in any medium, provided the original work is properly cited. 